\title{
Feasibility of a Pilot Study using Reversal Theory States to Test Holistic Interventions to Maximize Cancer Survivors' Quality of Life
}

\author{
Daniel C. Hughes, Alexis Ortiz, Luz Garcini, \\ Monica Serra, Lisa Kilpela, Darpan Patel, \\ Dorothy Long Parma, Edgar Munoz, \\ Angelika Lapetoda, and Amelie G. Ramirez \\ University of Texas Health \\ Nydia Tijerina Darby \\ Nydia's Yoga Therapy
}

\author{
Julissa Marin \\ California State University
}

Brandi T. Cuevas
Private Practioner

\begin{abstract}
The concept of maximizing health-related quality of life (HR-QOL) considers optimal outcomes for the physical, mental, and spiritual aspects defining what it means to be human. For a cancer survivor, i.e., an individual after receiving a diagnosis of cancer, the effects of cancer negatively impacts their HR-QOL. In traditional Western medicine practice, the primary focus is often "siloed" on physical functioning without accounting for other critical aspects of survivors' HR-QOL. A holistic approach to HR-QOL, including motivation, is needed to maximize the outcomes of each individual survivor. In this paper, we discuss the feasibility and methodology of a pilot study to test such a holistic approach using a 16-week intervention to maximize HR-QOL for 29 adult cancer survivors (at any stage of treatment). Participants will take a comprehensive assessment of their physical, mental, and spiritual wellbeing, including a qualitative interview at baseline and at weeks 8 and 16, and a follow-up 6-months later. The intervention will include yoga-based exercise with meditation, additional home-based fitness exercises, and necessary diet counseling. Through an interactive tele-health application, text messaging will be employed to enhance compliance behavior and provide psychosocial support in real time. The text messaging is specific to each individual motivational state as defined by Reversal Theory. We pre-tested the protocol with six volunteer cancer survivors to improve the protocol prior to implementing the current pilot and enrolling participants. The feedback provided by the six survivors is summarized here along with details of the final protocol focusing on the utilization of Reversal Theory state measures.
\end{abstract}

Keywords: holistic, cancer survivors, quality of life, psychosocial, reversal theory

\section{Introduction}

\section{Cancer Survivorship \& Health-Related Quality of Life}

The American Cancer Society predicts an estimated 1.7 million new cases of cancer in 2019, adding to the 15 million cancer survivors living in the U.S. on January 1, 2016 (American Cancer Society, 2019). A cancer survivor is defined as an individual after receiving a diagnosis of cancer (American Cancer Society, 2019). Survival rates are increasing due to earlier detection technologies coupled with effective individualized treatments. However, the deleterious effects of the cancer experience on physical capacity, mental wellbeing, and connectedness affect a cancer survivor's healthrelated quality of life (HR-QOL). Research and traditional medicine have focused on only one aspect of HR-QOL, physical functioning. A holistic approach, tailored specifically for the needs of each individual survivor, is essential to optimize HR-QOL outcomes (Satija \& Bhatnagar, 2017).

The improved early detection of cancer and treatments and the resultant increase in survival rates continues to shift the paradigm of a cancer diagnosis from less of a terminal to more of a chronic disease (American Cancer Society, 2019; Witter \& Le Bas, 2008). However, cancer treatments to defeat the cancer often lead to tissue damage to an otherwise healthy functioning body. These effects may manifest immediately or not for years and can include cardiotoxicity, cognitive issues ("chemo-brain"), fatigue, and sexual dysfunction (Ainsworth, Irwin, Addy, Whitt, \& Stolarczyk, 1999; American Cancer Society, 2019; Campbell et al., 2019). These detrimental effects and the need to deal with a long-term chronic disease have contributed to an ever-increasing emphasis on maximizing quality of life (QOL) for cancer survivors (National Cancer Institute, 2019). Throughout the 
continuum of the cancer journey, from diagnosis to "cancer free" remission, challenges affect every survivor who lives through this experience (Bellettieri, 1993; Costanzo, Stawski, Ryff, Coe, \& Almeida, 2012; Harms et al., 2019). Lower HR-QOL affects the majority of all survivors to some extent, regardless of cancer site and stage of treatment (Bluethmann, Sciamanna, Winkels, Sturgeon, \& Schmitz, 2018; Cleeland et al., 2000; Harms et al., 2019).

Though HR-QOL is a generally well-understood concept, an exact definition for a cancer survivor can vary depending on context. The National Cancer Institute defines quality of life as "the overall enjoyment of life." Many clinical trials have assessed the effects of cancer and its treatment on HRQOL. These studies measure aspects of an individual's sense of well-being and ability to carry out activities of daily living (National Cancer Institute, 2019). We propose that this definition be expanded to include optimal possible outcomes for the suvivor's physical, mental, and spiritual life, given their individual circumstances.

\section{Exercise and Cancer Survivorship HR-QOL}

Overwhelming evidence continues to demonstrate the benefits of exercise in reducing morbidity and mortality while improving individual HR-QOL and overall health (U.S. Department of Health and Human Services, 2018).

Daniel C. Hughes, Institute for Health Promotion Research, University of Texas Health; Julissa Marin, California State University, Long Beach; Alexis Ortiz, School of Physical Therapy, University of Incarnate Word; Luz Garcini, Center for Research to Advance Community Health (REACH), University of Texas Health; Angelika Lapetoda, Nydia's Yoga Therapy, San Antonio; Nydia Tijerina Darby, Nydia's Yoga Therapy, San Antonio; Monica Serra, Barshop Institute for Aging, University of Texas Health; Corina Zamora, Department of Psychiatry, University of Texas Health; Lisa Kilpela, Department of Psychiatry, University of Texas Health; Darpan Patel, Barshop Institute for Aging, University of Texas Health; Brandi T. Cuevas, Private Practioner, San Antonio; Dorothy Long Parma, Institute for Health Promotion Research, University of Texas Health; Edgar Munoz, Institute for Health Promotion Research, University of Texas Health; Amelie G. Ramirez, Population Health Sciences, University of Texas Health.

Grant/Funding information: Mays Cancer Center - Office of Sponsored Programs P30 CA054174. The University of Texas Health Science Center at San Antonio. Pilot grant institute funding Mays Cancer Center, Principal Investgator, Daniel Hughes).

Acknowledgements: The authors wish to acknowledge the contributions from our six cancer survivor volunteer members for their willingness to give us their valuable time and constructive feedback. The authors also wish to acknowledge the contributions from Dr. Mitzi Desselles and Dr. Michael Apter for their initial suggestions and review of the psychosocial support messages.

Correspondence concerning this article should be addressed to Daniel C. Hughes. E-mail: hughesdc@uthscsa.edu
These benefits may be even more influential in cancer survivors who are at elevated risk for functional and metabolic comorbidities beyond that of their age-matched, non-cancer counterparts. Evidence supporting a beneficial association between levels of exercise and the continuum of the cancer experience continues to accumulate (Campbell et al., 2019). A physically active lifestyle improves cancer survivors' wellbeing (Campbell et al., 2019; Farris, Courneya, O'Reilly, \& Friedenreich, 2018; Mustian et al., 2017) while reducing their risk of other comorbidities (Schwartz, de Heer, \& Bea, 2017; Squires, Shultz, \& Herrmann, 2018) of new and recurrent cancers (Arem et al., 2014; Friedenreich, Neilson, Farris, \& Courneya, 2016).

Despite the recognized benefits, at least two-thirds of cancer patients and survivors are not meeting physical activity recommendations. Multiple factors contribute to the low uptake of physical activity for cancer survivors. Eighty percent of oncology physicians and nurses report they do not know the proper exercise guidelines or healthy lifestyle services for cancer patients (Squires et al., 2018). Treatment effects such as fatigue, pain, and loss of functioning also contributes to a decline in cancer survivor's level of physical activity after diagnosis and without a return to former levels post treatment (Courneya et al., 2009). An important negative effect of minimal physical activity is a change in an individual's body composition, which can lead to obesity (Ladabaum, Mannalithara, Myer, \& Singh, 2014). Obesity and inactivity are associated with higher risk for cancer recurrence and mortality for many cancers (American Cancer Society, 2019; Campbell et al., 2019). Therefore, it is critical to continue to investigate effective strategies to encourage and engage cancer survivors in physically active behaviors.

\section{Applying a Behavioral Model to Exercise}

The need to engage cancer survivors to be more active has driven our research agenda and led to the creation and development of a behavioral model (with behavioral and biological implications) for exercise behaviors. Our model, however, is generalizable to other cancer prevention and control behaviors, such as screening, smoking cessation, and health-enhancing diet choices. In our model, motivational state is the key that ultimately dictates whether a specific behavior will or will not occur. We employ motivational states as defined by Reversal Theory (RT), (Apter, 2001), which is a general theory of motivation, emotion, and personality. Per our model, directly driving the ultimate decision is the individual's motivational state as defined by RT at the time of the decision. RT describes how motivational states drive behavior and suggests that certain motivational states are associated with certain cancer prevention and control behaviors such as diet (Popkess-Vawter, Wendel, Schmoll, \& O'Connell, 1998), smoking cessation (Burris \& O’Connell, 2003; O’Connell, Gerkovich \& Cook, 1995; 


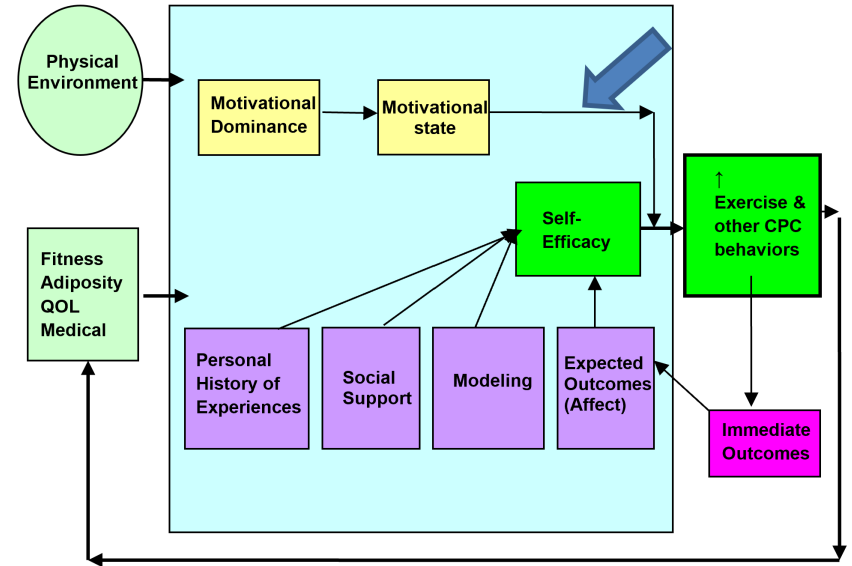

Figure 1. Behavioral model for exercise and other cancer prevention behaviors

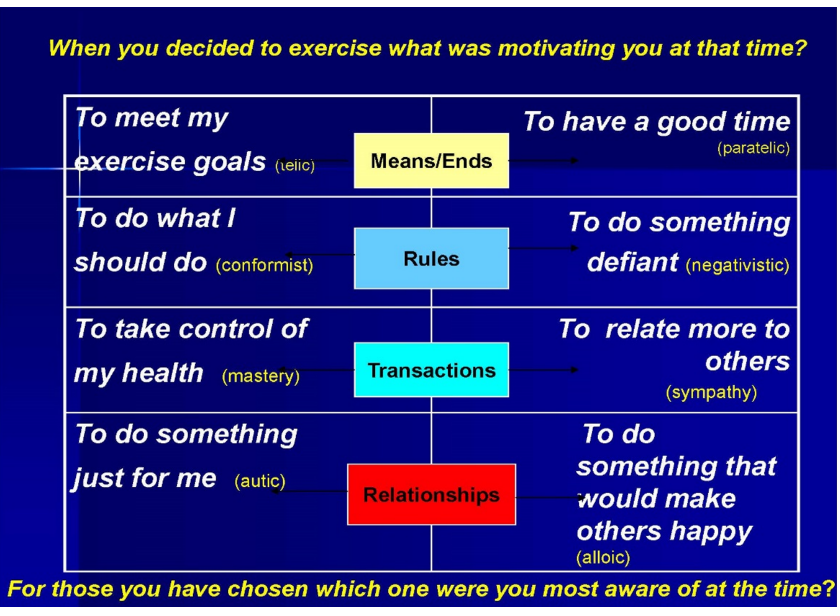

Figure 2. Motivational state questionnaire for endometrial cancer survivors before exercise

Cook, Gerkovich, O’Connell \& Potocky, 1995), and exercise (Sit, Kerr, \& Wong, 2008; Hughes, Baum, Perkins, \& BasenEngquist, 2009).

As shown in Figure 1, our model "flows" from left to right and then top to bottom. Environmental variables (e.g., perceived safety in neighborhood, sidewalks) and participant physical characteristics (poor functional capacity, obesity, medical history) influence the cognitive processes (large blue box) involved in the ultimate decision to engage or to not engage in a cancer prevention and control behavior. According to Social Cognitive Theory, (Bandura, 1986), the key cognition that drives behavior is self-efficacy. For exercise and other cancer prevention behaviors, primary sources of efficacy information can include personal exercise experience, social support, modeling, and exercise affect interpretation. In our model, cognitive constructs based on Social Cognitive Theory (SCT) (social support, modeling, affect, previous history) feed into very domain-specific self-efficacy.
As posited by SCT, if there is enough self-efficacy, the behavior is likely to happen. However, there is still no certainty the behavior will occur. Having a requisite level of self-efficacy toward a behavior does not necessarily translate into action. Mediated by that, in a sense, is an on-off switch of the "last" neuron to fire, which is triggered just prior to the behavior by an individual's motivational state at that instance. Thus, our model proposes that cancer prevention and control behaviors are ultimately a function of both a requisite level of confidence (self-efficacy; purple boxes) and an individual's motivational state (yellow boxes) at the time the individual considers the decision to engage or not engage in the behavior.

As an analogy (blue arrow), cognitive processing is the key and the motivational state is the hand that turns the key. The motivational state that is most salient is what ultimately unlocks and opens the door leading to the behavior or keeps it from opening. Consistent with RT, the motivational state that turns the key could be different from one bout of behavior activity to another. As has been stated by Dr. Apter, "we are dancers not statutes;" therefore, in designing an intervention to facilitate cancer survivors' engagement in cancer prevention behaviors, supportive information to "turn the key" should be framed to a participant's particular state.

Thus, our model suggests that providing psychosocial support text-messaging consistent with an individual's motivational state at the time that they are anticipating engaging or not engaging in a health enhancing behavior will be conducive to the individual engaging in the behavior.

\section{Applying RT to Exercise Interventions for Cancer Sur- vivors}

We have been working toward the application of RT to enhance exercise behaviors for cancer survivors over several studies. Our work to date has included endometrial, breast cancer, and prostate cancer survivors. We present a brief description of each to illustrate the evolution of our tailoring approach that has ultimately led us to test the feasibility of our pilot research.

To begin to validate the RT portion of our model, we engaged 94 post-treatment endometrial cancer survivors who did not meet public health guidelines for exercise to a sixmonth exercise program (Basen-Engquist et al., 2011). We collected motivational dominance as well with the Apter Motivational Style Profile (AMSP) (Apter International, 2004). In what was then "cutting edge" technology, we asked them to respond to a RT state measure using a smart handheld device. Participants opened the survey on their device right before they decided to engage in exercise. As shown in Figure 2, participants chose one state from each pair of states. After endorsing their four current states, participants answered which of the four they were most aware of at that instant. 


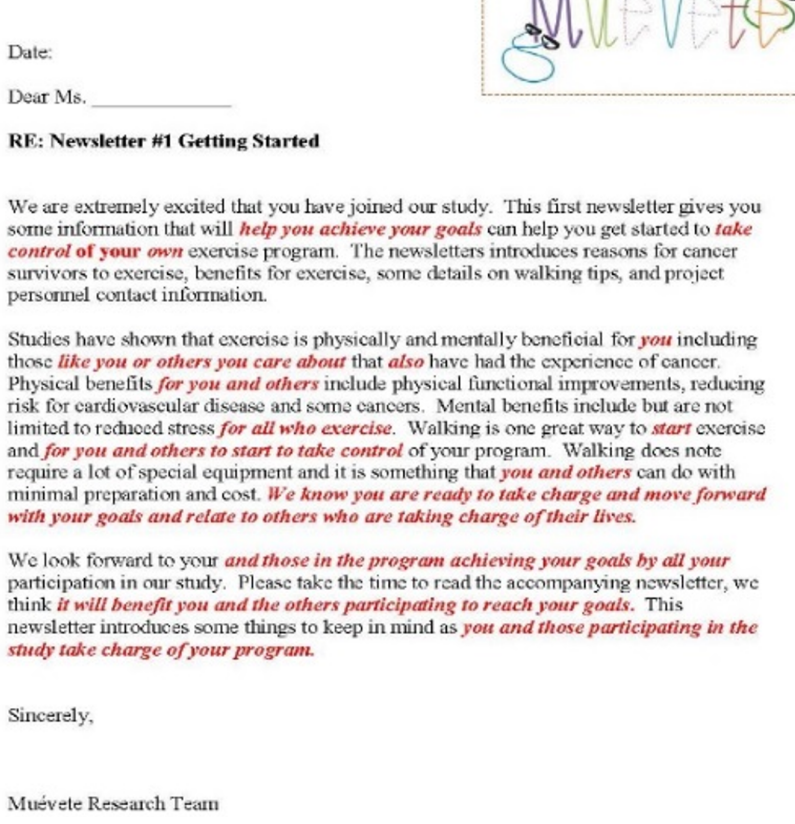

Figure 3. Sample of the introductory letter

These were collected the week before and the week after each lab visit (baseline, 2 months, 4 months, and 6 months). Results indicate that the participants endorsed mostly mastery state $(39 \%)$ followed by closely by the telic state (36 $\%$ ) (Hughes, Baum, Perkins, \& Basen-Engquist, 2009). A limitation to this approach was that we did not collect data after exercise to compare whether there was a change in state as result of exercise. We concluded that the process of conforming to our request to take the survey prior to engaging in exercise might have in fact resulted in inducing a mastery or telic state. Another confounding factor may have been that responses were heavily skewed toward the first of each pair (i.e. responding $1,1,1,1$ ), perhaps to finish the survey more quickly. Based on our direction for this pilot project, we plan to return to this dataset to conduct a secondary analysis (manuscript under development).

We also applied RT to tailor an exercise intervention in the South Texas-Mexico border area with Mexican-American breast cancer survivors. However here we focused on dominance versus state. In this trial we randomized 38 post-treatment breast cancer survivors to either receive a culturally-adapted biweekly newsletter based on SCT along with an individually tailored introductory newsletter based on participant dominance. The control group received a usual-care version of the biweekly newsletter without cultural adaptation as well as the introductory letter without tailoring. We hypothesized that those participants receiving the adapted and tailored material would be more compliant to the exercise program prescribed for them than those who did not
Letting friends and family know about your need to exercise is importantl Invite them to join you in your activities.

Text us your SMART goal for the next 2 weeks!

(1/2) If you don't think you can do all of your exercise for the day, do just 5 minutes and then see how you are doing. Squeeze in exercise by

(2/2) taking the stairs, parking further away from your destination, or walking while on the phone. Text back WALK if you agree to try.

\begin{tabular}{l}
\hline YES or NO: Are you keeping a daily log of your exercise? \\
\hline If positive: "Great!" If negative: "Give it a try. Monitoring your \\
exercise will help you achieve your exercise goals."
\end{tabular}

Figure 4. Example of Movember GAP-4 psychosocial support text

(Hughes, Garcia, Treviño, Morris, \& Ramirez, 2013). The newsletters were based on the study performed with endometrial cancer survivors (Basen-Engquist et al., 2011) and with the material based on SCT. Seven newsletters were sent including topics for:
Newsletter 1: Getting Started
Newsletter 2: Goal Setting
Newsletter 3: Energy Balance
Newsletter 4: Getting Confident
Newsletter 5: Uncovering Barriers
Newsletter 6: Lapsing/Relapsing/Collapsing
Newsletter 7: Continuing to Be Active

Newsletters and all communications for this population were offered in language of choice (English and Spanish). To introduce the newsletters, we tailored an introductory letter for the intervention group participants based on each participant's dominance score from the AMSP. Due to limited resources, we limited our tailoring to telic and autic dominances (telic-paratelic; autic-alloic). Figure 3 is an example of a tailored introductory newsletter for a participant who scored high in telic dominance and alloic dominance.

In another example, this paper's first author developed the psychosocial support for the Movember Global Action Plan 4 initiative for castrate resistant metastatic prostate cancer survivors. This used supportive text messages in the same 


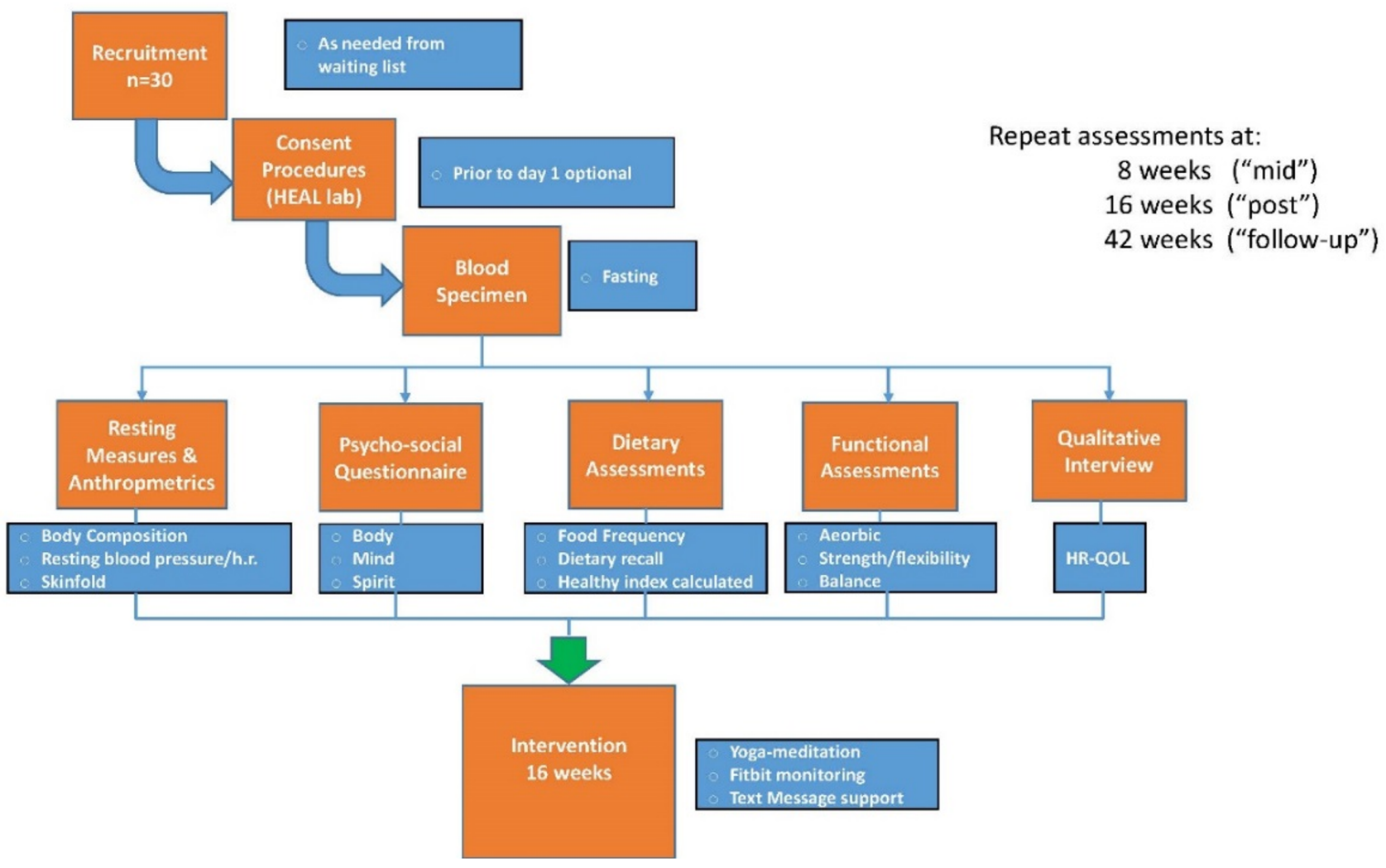

Figure 5. Study design

manner as we are proposing to do here (Newton et al., 2018). Though not directly based on RT, the messages were framed using phrases/messages consistent with SCT and the Theory of Planned Behavior. For our proposed pilot study, we plan to embellish the methodology employed in the Moveember study, which sends text messages for enhancing exercise behaviors using a HIPPA compliant telehealth application (BlueJay Mobile-Health, Pleasanton, CA). In the Movember study, which includes 17 sites in 8 countries, participants are enrolled for two years and overall survival is the primary outcome. As participants proceed from supervised exercise to unsupervised exercise, the frequency of text messaging is increased and is more supportive in nature. Figure 4 shows an example of such a message. Forty-eight prostate cancer survivors have completed thus far. The project team asked them to provide qualitative feedback on their perceptions on whether the text messaging helped them or hindered them; 45 said yes; three said no. Other responses are under review.

\section{Methods for Proposed Study}

The design of the study is shown in Figure 5.

\section{Rationale of Approach}

Because of the novelty of this approach, the anticipated range in functionality of the potential participants, and to en- sure the least burdensome assessment procedures from a survivor's standpoint, we pre-tested the pilot protocol with six volunteer cancer survivors before recruiting the cohort of survivors for the actual feasibility study. See Table 1 for changes we made to the study based on this pre-test. For this feasibility study, we have three major objectives. 1) Successfully engage adult cancer survivors to complete a 16-week pilot intervention including yoga-based exercise with one meditation, an individualized exercise program as needed, diet improvement guidance, and psychosocial support text messaging based on the survivors' individual motivational state delivered through a telehealth portal. 2) Demonstrate the feasibility, safety, and cost effectiveness of such an intervention. 3) Monitor the long-term impact by conducting follow-up assessments six months after the 16-week active portion is complete. For this paper, we will focus on describing the research methodology for objective \#2 (testing the feasibility of such an intervention).

\section{Participants}

To test the feasibility of the instruments and procedures of the pilot, we requested that six cancer survivors serve as an external advisory group to provide feedback on our instruments and procedures. The advisory group was formed by three female (two breast and one thyroid) survivors and three male (prostate, colo-rectal, lymphoma) survivors with 
Table 1

Revisions to Study as Proposed by Pre-Study Volunteer Survivors

\begin{tabular}{|c|c|c|c|}
\hline Survivor & Cancer Site & Suggestions & Resolution \\
\hline \multirow[t]{2}{*}{1} & Prostate & $\begin{array}{l}\text { Food frequency questionnaire long time to com- } \\
\text { plete if interviewer driven }\end{array}$ & $\begin{array}{l}\text { Food frequency changed to be completed by partic- } \\
\text { ipant }\end{array}$ \\
\hline & & No sexual functioning questions & $\begin{array}{l}\text { Added instrument that includes sexual functioning } \\
\text { statement }\end{array}$ \\
\hline \multirow[t]{2}{*}{2} & Breast & Psycho-social packet too long & Reduced by $25 \%$ \\
\hline & & $\begin{array}{l}\text { Too many proposed text messages for psycho-social } \\
\text { support }\end{array}$ & $\begin{array}{l}\text { One message per day scheduled at time chosen by } \\
\text { patient }\end{array}$ \\
\hline 3 & $\begin{array}{l}\text { Thyroid } \\
\text { (female) }\end{array}$ & $\begin{array}{l}\text { Coming in on two days one week apart too demand- } \\
\text { ing on patient }\end{array}$ & Consolidated assessments on one day only \\
\hline \multirow[t]{2}{*}{4} & $\begin{array}{l}\text { Colo-rectal } \\
\text { (male) }\end{array}$ & $\begin{array}{l}\text { Atmosphere too cold - need pictures slogans } \\
\text { "warmer atmosphere" }\end{array}$ & $\begin{array}{l}\text { Decorated lab with pictures and motivational slo- } \\
\text { gans }\end{array}$ \\
\hline & & $\begin{array}{l}\text { Inconsistent wording between informed consent } \\
\text { document and descriptive material }\end{array}$ & $\begin{array}{l}\text { Informed consent document is "boilerplate" and } \\
\text { cannot be changed. }\end{array}$ \\
\hline 5 & Breast & $\begin{array}{l}\text { Food frequency questionnaire too long to be inter- } \\
\text { viewee driven }\end{array}$ & Changed procedure to let participants do \\
\hline 6 & $\begin{array}{l}\text { Lymphoma } \\
\text { (male) }\end{array}$ & $\begin{array}{l}\text { Qualitative interview should be on separate sessions } \\
\text { - too much too do at once }\end{array}$ & $\begin{array}{l}\text { Deleted time-consuming assessments (portable } \\
\text { measure of respiratory gases, gait analyses) and } \\
\text { combined sessions into one day. }\end{array}$ \\
\hline
\end{tabular}

Table 2

Primary Outcome Measures

\begin{tabular}{|c|c|c|}
\hline $\begin{array}{c}\text { Body } \\
\text { Physical Functioning Outcomes }\end{array}$ & $\begin{array}{c}\text { Mind } \\
\text { Mental Outcomes }\end{array}$ & $\begin{array}{c}\text { Spirit } \\
\text { Spiritual Outcomes }\end{array}$ \\
\hline $\begin{array}{l}\text { Anthropometric: body fatness, thoracic } \\
\text { mobility } \\
\text { Aerobic: six-minute walk test } \\
\text { Gait: balance } \\
\text { Strength: hand grip dynamometry } \\
\text { Flexibility: sit and reach test } \\
\text { Self-reported pain: Visual Analog Pain } \\
\text { Scale (Medical Outcomes SF-36- } \\
\text { physical function related scales) } \\
\text { Blood chemistry } \\
\text { Accelerometry } \\
\text { Self-reported physical activity } \\
\text { Diet: Block Food Frequency Questionnaire, } \\
\text { including calculation of a healthy eating } \\
\text { index } \\
\text { 24-Hour dietary recall }\end{array}$ & $\begin{array}{l}\text { Apter Metamotivational Style Profile } \\
\text { (AMSP) } \\
\text { Medical Outcomes Short Form-36 (SF-36) } \\
\text { related scales } \\
\text { Perceived Stress Scale (PSS) } \\
\text { Pittsburg Sleep Quality Index (PSQI) } \\
\text { Center for Epidemiological Studies } \\
\text { Depression Scale (CES-D) } \\
\text { Body Image Scale (BIS) for Cancer } \\
\text { Survivors } \\
\text { Pain Scale (Visual Analog Pain scale) } \\
\text { Brief Symptom Inventory (BSI-18) } \\
\text { Self-report qualitative interview results } \\
\text { Social Cognitive Theory (SCT) constructs: } \\
\text { self-efficacy, barriers self-efficacy, } \\
\text { modeling, self-id as exerciser }\end{array}$ & $\begin{array}{l}\text { Functional Assessment of Chronic Illness } \\
\text { Therapy-Spiritual Well-being } \\
\text { (FACIT-SP) } \\
\text { Adult Dispositional Hope Scale (ADHS) } \\
\text { Personal Meaning Profile (PMP) } \\
\text { Self-report QOL qualitative interview } \\
\text { results } \\
\text { Social Cognitive Theory (SCT) constructs: } \\
\text { social support of family/friends }\end{array}$ \\
\hline
\end{tabular}

a correspondingly wide range in health functioning status. This helped us test the anticipated variability in the survivors that would be enrolled. All six survivors were ambulatory and had no limitations in performing their activities of daily living (ADL's).

Inclusion criteria for the study is any adult ( $>18$ years of age) cancer survivor at any stage of treatment and cancer type. The only exclusion criteria is any absolute contraindication to exercise testing as detailed by the American College of Sports Medicine Guidelines (American College of Sports
Medicine, 2018). As detailed in the status section below, we have successfully recruited 30 survivors who passed screening for eligibility and were invited to participate. Out of the 30 invited, 29 came to the lab, provided informed consent and completed baseline assessments.

\section{Assessments \& Measures}

The six survivors of the advisory group went through the entire original baseline assessment sequence (not shown). 
Based on their recommendations, the questionnaires were reduced by $25 \%$. Two of the more time-consuming physical functioning performance tests were eliminated. This facilitated physical functioning assessments to be completed more quickly (participant burden was reduced approximately 60 minutes). Two of the male members repeated the baseline assessments a few weeks later to evaluate the improvements in the procedures. They agreed that the new procedures were more tailored to their time commitment and physical abilities and that the proposed study was ready to recruit a cohort of adult survivors to test the feasibility of our approach.

As shown in Figure 5, participants will provide fasting blood specimens to measure for proxy bio-markers for cancer recurrence risk; complete a comprehensive psychosocial questionnaire packet that includes the Apter Motivational Style Profile (AMSP), followed by the 2014 Block Food Frequency Questionnaire (FFQ) (Block, Gillespie, Rosenbaum, \& Jenson, 2000), and a 24-hour dietary recall. Participants will then complete physical/functional assessments of cardiorespiratory, strength, and flexibility. After all assessments, they will answer a semi-structured interview on how they interpret their quality of life in a typical day and in the best day imaginable. The specific measures are listed in Table 2 and can be made available upon request.

\section{Psychosocial Support Text Messaging}

Motivational strategies to enhance compliance will be comprised of electronic messaging using the BlueJay Mobile-Health tele-medicine platform, (Livermore, CA). This tele-health, HIPAA compliant, computer/smartphone application allows text messaging and private communication between health care professionals and participants. The support messages will encourage participation in prescribed health enhancing behaviors. The support messages will be based on a previously developed text-based support system to foster exercise behaviors in metastatic prostate cancer survivors (Newton et al., 2018).

Supportive tailored messages. During baseline assessments in week 0 and after receiving consent from the participants, participants will choose a preferred time to receive text messaging. The approximate time selected will prompt each participant to respond and reply to the motivational state survey. We will start with one message per day per participant (six supportive, tailored, text messages for each week, one message each day of the week and one on weekends).

The tailored messages are the core support for each participant. One of a possible eight sets of messages will be used to enhance and revise the original text message. These sets of messages will be tailored based on the participants chosen language (Spanish or English) and current motivational state as determined by the Reversal Theory State Measure (Bundled Version) (Desselles, Murphy, \& Theys, 2014). With this instrument, data will be returned in three nomi-

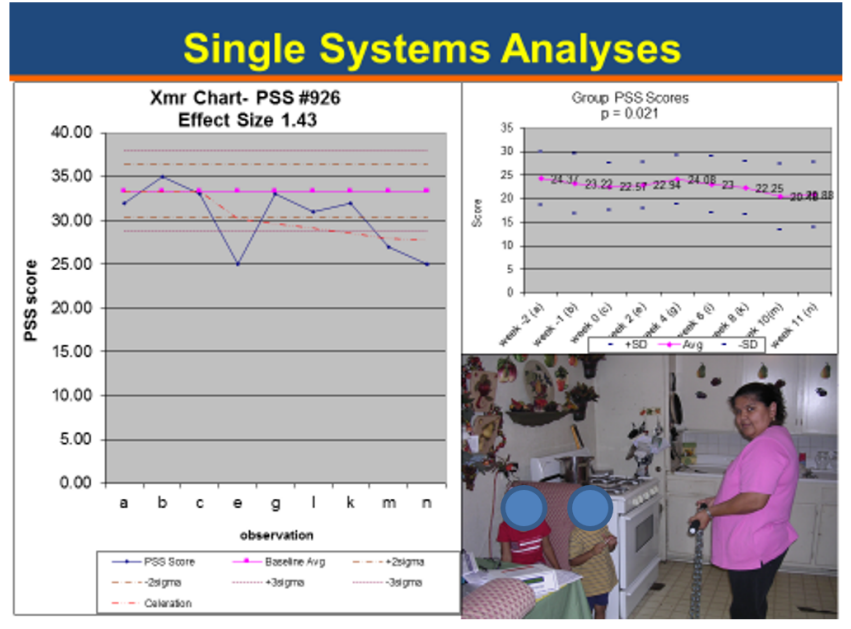

Figure 6. Single system analysis example

nal variables. Two are dichotomous: telic versus paratelic and conforming versus negativistic. One is a four-category nominal variable representing the crossed pairs of transactional states: autic-mastery, autic-sympathy, alloic-mastery, and alloic-sympathy. After consulting with Dr. Desselles, the author of the state measure, it was determined to start with two separate messages spaced 30 seconds apart. The first message will consist of a message tailored around the pairing of the first two dichotomous responses (telic-paratelic results crossed with conformist-negativistic). Next, a second supportive tailored message will be based on the participant's response to the autic/alloic-sympathy/mastery variable.

Since this 16-week pilot intervention is a focused feasibility study of using supportive tailored messaging, instead of developing messages for all 16 weeks, we wrote messages for the first 3 weeks. As we obtain feedback from the survivors, we anticipate adjustments will be made to improve the process. Tables 3 thorough 8 illustrate the first three weeks of tailored messages.

\section{Data Analysis}

The targeted sample size of 30 for this one-armed feasibility pilot study was based on logistic limitations, as no formal hypothesis can be generated for a feasibility study. Participants will act as their own controls in a paired repeatedmeasures design. Continuously-distributed outcomes will be summarized by descriptive statistics. Categorical outcomes will be summarized with counts and percentages. Continuously-distributed outcomes will be carried out with repeated-measured analysis of co-variance (ANCOVA), controlling for the initial value of the measure of interest.

In addition, single-systems analysis (SSA) will be used as a second statistical strategy. SSA can be conceived as treating each individual as a separate study from an ecological validity standpoint (Bloom, Fischer, \& Orme, 2006). Fol- 
Table 3

First Three Weeks of Support Messages Based on Reversal Theory State (Messages 1-3)

\begin{tabular}{|c|c|c|c|c|}
\hline $\begin{array}{l}\text { Msg } \\
\text { ID }\end{array}$ & Week & $\begin{array}{l}\text { Day } \\
\text { of } \\
\text { week }\end{array}$ & Participant's RT State & Message \\
\hline \multirow[t]{8}{*}{1} & \multirow[t]{8}{*}{1} & \multirow[t]{8}{*}{ Mon } & Telic-Conforming & It will take time to reach your goal but sticking with your plan will get you there. \\
\hline & & & Telic-Negativistic & Be prepared to try something new to achieve something truly meaningful. \\
\hline & & & Paratelic-Conforming & $\begin{array}{l}\text { Life is a journey. Doing what is expected can make the journey less confusing and } \\
\text { every moment more enjoyable. }\end{array}$ \\
\hline & & & Paratelic-Negativistic & $\begin{array}{l}\text { Old ways just will not cut it anymore. Have fun re-inventing yourself as you go down } \\
\text { this fun road less traveled toward wellness. }\end{array}$ \\
\hline & & & Autic-Mastery & $\begin{array}{l}\text { You may not control everything that happens, but you can control everything that you } \\
\text { do. Positive changes make a positive difference toward your personal well being. }\end{array}$ \\
\hline & & & Autic-Sympathy & $\begin{array}{l}\text { Sometimes, you need to do what is best for your health. It is more than ok; it is } \\
\text { necessary to achieve that optimal life balance. Looking after yourself is not a bad } \\
\text { thing. }\end{array}$ \\
\hline & & & Alloic-Mastery & $\begin{array}{l}\text { Your strength can inspire others. Be a force for good as role model for others to } \\
\text { improve their health and well being. }\end{array}$ \\
\hline & & & Alloic-Sympathy & $\begin{array}{l}\text { Be the reason to be someone's joy. Your example may bring them cheer and cheer is } \\
\text { important for our mental well-being. }\end{array}$ \\
\hline \multirow[t]{8}{*}{2} & \multirow[t]{8}{*}{1} & \multirow[t]{8}{*}{ Tues } & Telic-Conforming & $\begin{array}{l}\text { Healing is when your body, mind, spirit are in harmony. Achieve harmony by em- } \\
\text { bracing the path to optimal wellness that you have just begun. }\end{array}$ \\
\hline & & & Telic-Negativistic & $\begin{array}{l}\text { Ask yourself where you're headed and what's really important to you. Then be open } \\
\text { to the possibility of change for a healthier, happier version of you. }\end{array}$ \\
\hline & & & Paratelic-Conforming & $\begin{array}{l}\text { Think about your path to wellness as a game and something to be enjoyed. In games } \\
\text { we enjoy, rules seem to make it more fun to play. }\end{array}$ \\
\hline & & & Paratelic-Negativistic & $\begin{array}{l}\text { Spice up today's routine by doing something unexpected or new or something you } \\
\text { always want to try but were hesitant to do and enjoy the break from the expectations. }\end{array}$ \\
\hline & & & Autic-Mastery & $\begin{array}{l}\text { Be fierce in your approach on the path toward becoming a better, healthier, happier } \\
\text { version of yourself. }\end{array}$ \\
\hline & & & Autic-Sympathy & $\begin{array}{l}\text { As you go down this path, don't hesitate to pamper yourself. You'll be better for it in } \\
\text { the long run and it just might be what you need. }\end{array}$ \\
\hline & & & Alloic-Mastery & $\begin{array}{l}\text { Set an example for someone who needs it, someone whose life you can touch on their } \\
\text { journey to better health. }\end{array}$ \\
\hline & & & Alloic-Sympathy & $\begin{array}{l}\text { Surprise someone today by reaching out to them and by telling them how much you } \\
\text { care for them and their well-being. }\end{array}$ \\
\hline \multirow[t]{8}{*}{3} & \multirow[t]{8}{*}{1} & \multirow[t]{8}{*}{ Wed } & Telic-Conforming & $\begin{array}{l}\text { Doing what's expected of you as you reach these goals for optimizing your health } \\
\text { and wellbeing can help bring you tranquility and inner peace. }\end{array}$ \\
\hline & & & Telic-Negativistic & $\begin{array}{l}\text { To reach your goal for a healthier you, old ways just won't cut it anymore. Be pre- } \\
\text { pared to re-invent yourself to succeed toward optimizing your well-being. }\end{array}$ \\
\hline & & & Paratelic-Conforming & $\begin{array}{l}\text { Keep going straight along this path you've begun and enjoy every step of the journey. } \\
\text { Nothing wrong with having a little bit of fun. }\end{array}$ \\
\hline & & & Paratelic-Negativistic & $\begin{array}{l}\text { Just for today. Be bold doing what you want for fun. Go ahead and do it with just the } \\
\text { "right" amount of bad. }\end{array}$ \\
\hline & & & Autic-Mastery & $\begin{array}{l}\text { The challenges you face are opportunities to show courage as you work for yourself } \\
\text { to maximize what your quality of life can become. }\end{array}$ \\
\hline & & & Autic-Sympathy & $\begin{array}{l}\text { Be kind to yourself. You deserve it. You may be hearing that a lot in the meditation } \\
\text { practices. }\end{array}$ \\
\hline & & & Alloic-Mastery & $\begin{array}{l}\text { Step outside yourself for a while and encourage someone else on their journey toward } \\
\text { health. They will more than probably appreciate your support. }\end{array}$ \\
\hline & & & Alloic-Sympathy & $\begin{array}{l}\text { Your sensitivity to the needs of other survivors can help them in special ways and at } \\
\text { time when they may need it most on their journey to a healthier happier self. }\end{array}$ \\
\hline
\end{tabular}


Table 4

First Three Weeks of Support Messages Based on Reversal Theory State (Messages 4-6)

\begin{tabular}{|c|c|c|c|c|}
\hline $\begin{array}{l}\text { Msg } \\
\text { ID }\end{array}$ & Week & $\begin{array}{l}\text { Day } \\
\text { of } \\
\text { week }\end{array}$ & Participant's RT State & Message \\
\hline \multirow[t]{8}{*}{4} & \multirow[t]{8}{*}{1} & \multirow[t]{8}{*}{ Thurs } & Telic-Conforming & $\begin{array}{l}\text { Your ultimate destination is a better version of you and what you can become. Please } \\
\text { keep going on this personal journey along this path you have begun. }\end{array}$ \\
\hline & & & Telic-Negativistic & $\begin{array}{l}\text { Be prepared to try something new to achieve something truly meaningful for yourself } \\
\text { on your health journey. }\end{array}$ \\
\hline & & & Paratelic-Conforming & $\begin{array}{l}\text { Knowing what to expect and meeting expectations of this program can make your } \\
\text { journey more fun as you travel toward a healthier, happier version of yourself. }\end{array}$ \\
\hline & & & Paratelic-Negativistic & $\begin{array}{l}\text { Fill your day today with some mischievous glee. Life is meant to be enjoyed even if } \\
\text { it means breaking a rule or two every once in a while. }\end{array}$ \\
\hline & & & Autic-Mastery & $\begin{array}{l}\text { Be your own custom creation. Define yourself and activate yourself to reach what } \\
\text { you can ultimately be. }\end{array}$ \\
\hline & & & Autic-Sympathy & $\begin{array}{l}\text { Create a no-guilt zone that you can visit regularly. It just may do some good as you } \\
\text { go down this rough road toward a healthier you - (visit but don't stay forever). }\end{array}$ \\
\hline & & & Alloic-Mastery & $\begin{array}{l}\text { Your strength and your experiences can inspire others to succeed on their journey } \\
\text { toward a healthier self. Use your experiences to be a strong force for good as a role } \\
\text { model. }\end{array}$ \\
\hline & & & Alloic-Sympathy & $\begin{array}{l}\text { Compassion for a fellow survivor should never wait. Reach out to a fellow survivor } \\
\text { today and let them know you are in their corner in the battled-ridden road to healthier } \\
\text { selves. }\end{array}$ \\
\hline \multirow[t]{8}{*}{5} & \multirow[t]{8}{*}{1} & \multirow[t]{8}{*}{ Fri } & Telic-Conforming & Nobody said working on achieving those positive health goals would be easy. \\
\hline & & & Telic-Negativistic & $\begin{array}{l}\text { Try something new today, do it your way toward a healthier, happier you - defy all } \\
\text { the odds to make it happen. }\end{array}$ \\
\hline & & & Paratelic-Conforming & $\begin{array}{l}\text { Straight, narrow and enjoyable is the path toward getting to those goals that have been } \\
\text { set for your quality of life program. }\end{array}$ \\
\hline & & & Paratelic-Negativistic & $\begin{array}{l}\text { Enjoy yourself today as you defy the odds and try something new and bold, it is ok to } \\
\text { enjoy the ride and break the rules every once in a while for your total healthier you. }\end{array}$ \\
\hline & & & Autic-Mastery & $\begin{array}{l}\text { You have your plan for making yourself a healthier you. Be adamant, stick to your } \\
\text { guns and be bold in doing it for yourself. }\end{array}$ \\
\hline & & & Autic-Sympathy & $\begin{array}{l}\text { Don't shrink from asking for emotional support for yourself at any time. Most people, } \\
\text { especially those who care personally for you, want to help you achieve better health } \\
\text { but may not know how. }\end{array}$ \\
\hline & & & Alloic-Mastery & $\begin{array}{l}\text { Let another survivor know that you believe in them and their capabilities to make a } \\
\text { difference in their lives toward a healthier, happier self. Knowing you believe in them } \\
\text { may help more than you might realize. }\end{array}$ \\
\hline & & & Alloic-Sympathy & $\begin{array}{l}\text { Be a good friend, a good supporter for someone who needs it, always a good time to } \\
\text { reach out to someone who needs encouragement and help them on their way. }\end{array}$ \\
\hline \multirow[t]{8}{*}{6} & \multirow[t]{8}{*}{1} & \multirow[t]{8}{*}{ wknd } & Telic-Conforming & $\begin{array}{l}\text { It will take time to reach your health goal but sticking with your specific plan will } \\
\text { enable for you get there where you want to go. }\end{array}$ \\
\hline & & & Telic-Negativistic & $\begin{array}{l}\text { Be open to the possibility of change in how you approach improving your quality of } \\
\text { life goals - this very well could bring new meaning to your life. }\end{array}$ \\
\hline & & & Paratelic-Conforming & $\begin{array}{l}\text { As you are following the pieces of the program set for you, ask yourself how you can } \\
\text { enjoy it more. Enjoy the ride. }\end{array}$ \\
\hline & & & Paratelic-Negativistic & $\begin{array}{l}\text { Take a detour and break the mold; truly enjoy the moment, the day and live the life } \\
\text { of freedom to do your thing. }\end{array}$ \\
\hline & & & Autic-Mastery & $\begin{array}{l}\text { The person who can challenge you the most to reach your health goals is the person } \\
\text { in the mirror. Master your approach in reaching what you want, a healthier, happier } \\
\text { you! }\end{array}$ \\
\hline & & & Autic-Sympathy & $\begin{array}{l}\text { There is nothing wrong with allowing others the opportunity be kind to you. Let them } \\
\text { know what you need. }\end{array}$ \\
\hline & & & Alloic-Mastery & $\begin{array}{l}\text { You can lighten someone's load by letting them know you believe in them to succeed; } \\
\text { sometimes a few words of encouragement can help other survivors at times when they } \\
\text { need it most. }\end{array}$ \\
\hline & & & Alloic-Sympathy & $\begin{array}{l}\text { It is ok to be compassionate for other survivors and let them know you care - pam- } \\
\text { per them with encouragement - it probably won't hurt, and it may just help them } \\
\text { tremendously to know they are in your thoughts. }\end{array}$ \\
\hline
\end{tabular}


Table 5

First Three Weeks of Support Messages Based on Reversal Theory State (Messages 7-9)

\begin{tabular}{|c|c|c|c|c|}
\hline $\begin{array}{l}\text { Msg } \\
\text { ID }\end{array}$ & Week & $\begin{array}{l}\text { Day } \\
\text { of } \\
\text { week }\end{array}$ & Participant's RT State & Message \\
\hline \multirow[t]{8}{*}{7} & \multirow[t]{8}{*}{2} & \multirow[t]{8}{*}{ Mon } & Telic-Conforming & $\begin{array}{l}\text { Fully embracing your individual plan every day can help bring a strong sense of } \\
\text { personal purpose to your life. }\end{array}$ \\
\hline & & & Telic-Negativistic & $\begin{array}{l}\text { Be prepared to try something new to achieve something truly meaningful for yourself } \\
\text { on your health journey. }\end{array}$ \\
\hline & & & Paratelic-Conforming & $\begin{array}{l}\text { Keep going straight along this path you've begun and enjoy every step of the journey. } \\
\text { Nothing wrong with having a little bit of fun. }\end{array}$ \\
\hline & & & Paratelic-Negativistic & $\begin{array}{l}\text { Enjoy yourself today as you defy the odds and try something new and bold, it is ok to } \\
\text { enjoy the ride and break the rules every once in a while for your total healthier you. }\end{array}$ \\
\hline & & & Autic-Mastery & $\begin{array}{l}\text { Be fierce in your approach on the path toward to becoming a better, healthier, happier } \\
\text { version of yourself. }\end{array}$ \\
\hline & & & Autic-Sympathy & $\begin{array}{l}\text { Don't shrink from asking for emotional support for yourself at any time. Most people, } \\
\text { especially those who care personally for you, want to help you achieve better health } \\
\text { but may not know how. }\end{array}$ \\
\hline & & & Alloic-Mastery & $\begin{array}{l}\text { Set an example for someone who needs it. Someone whose life you can touch on } \\
\text { their journey to better health. }\end{array}$ \\
\hline & & & Alloic-Sympathy & $\begin{array}{l}\text { Surprise someone today by reaching out to them and by telling them how much you } \\
\text { care for them and their well-being. }\end{array}$ \\
\hline \multirow[t]{8}{*}{8} & \multirow[t]{8}{*}{2} & \multirow[t]{8}{*}{ Tues } & Telic-Conforming & $\begin{array}{l}\text { Healing is when your body, mind, spirit are in harmony. Achieve harmony by em- } \\
\text { bracing the path to optimal wellness that you have just begun. }\end{array}$ \\
\hline & & & Telic-Negativistic & $\begin{array}{l}\text { To reach your goal for a healthier you, old ways just won't cut it anymore. Be pre- } \\
\text { pared to re-invent yourself to succeed toward optimizing your well-being. }\end{array}$ \\
\hline & & & Paratelic-Conforming & $\begin{array}{l}\text { Knowing what to expect and meeting expectations of this program can make your } \\
\text { journey more fun as you travel toward a healthier, happier version of yourself. }\end{array}$ \\
\hline & & & Paratelic-Negativistic & $\begin{array}{l}\text { Spice up today's routine by doing something unexpected or new or something you } \\
\text { always want to try but were hesitant to do and enjoy the break from the expectations. }\end{array}$ \\
\hline & & & Autic-Mastery & $\begin{array}{l}\text { Be your own custom creation. Define yourself and activate yourself to reach what } \\
\text { you can ultimately be. }\end{array}$ \\
\hline & & & Autic-Sympathy & $\begin{array}{l}\text { Be kind to yourself. You deserve it. You may be hearing that a lot in the meditation } \\
\text { practices. }\end{array}$ \\
\hline & & & Alloic-Mastery & $\begin{array}{l}\text { Your strength can inspire others. Be a force for good as role model for others to } \\
\text { improve their health and well being. }\end{array}$ \\
\hline & & & Alloic-Sympathy & $\begin{array}{l}\text { Your sensitivity to the needs of other survivors can help them in special ways and at } \\
\text { time when they may need it most on their journey to a healthier happier self. }\end{array}$ \\
\hline \multirow[t]{8}{*}{9} & \multirow[t]{8}{*}{2} & \multirow[t]{8}{*}{ Wed } & Telic-Conforming & $\begin{array}{l}\text { Your best outcomes for maximizing your quality of life will come from adhering to } \\
\text { your plan - stay on the path. }\end{array}$ \\
\hline & & & Telic-Negativistic & $\begin{array}{l}\text { Ask yourself where you're headed and what's really important to you. Then be open } \\
\text { to the possibility of change for a healthier, happier version of you. }\end{array}$ \\
\hline & & & Paratelic-Conforming & $\begin{array}{l}\text { Life is a journey. Doing what is expected can make the journey less confusing and } \\
\text { every moment more enjoyable. }\end{array}$ \\
\hline & & & Paratelic-Negativistic & $\begin{array}{l}\text { Old ways just will not cut it anymore. Have fun re-inventing yourself as you go down } \\
\text { this fun road less traveled toward wellness. }\end{array}$ \\
\hline & & & Autic-Mastery & $\begin{array}{l}\text { You may not control everything that happens, but you can control everything that you } \\
\text { do. Positive changes make a positive difference toward your personal well being. }\end{array}$ \\
\hline & & & Autic-Sympathy & $\begin{array}{l}\text { Sometimes, you need to do what is best for your health. It is more than ok; it is } \\
\text { necessary to achieve that optimal life balance. Looking after yourself is not a bad } \\
\text { thing. }\end{array}$ \\
\hline & & & Alloic-Mastery & $\begin{array}{l}\text { Your strength and your experiences can inspire others to succeed on their journey } \\
\text { toward a healthier self. Use your experiences to be a strong force for good as a role } \\
\text { model. }\end{array}$ \\
\hline & & & Alloic-Sympathy & $\begin{array}{l}\text { Be the reason to be someone's joy. Your example may bring them cheer and cheer is } \\
\text { important for our mental well-being. }\end{array}$ \\
\hline
\end{tabular}


Table 6

First Three Weeks of Support Messages Based on Reversal Theory State (Messages 10-12)

\begin{tabular}{|c|c|c|c|c|}
\hline $\begin{array}{l}\text { Msg } \\
\text { ID }\end{array}$ & Week & $\begin{array}{l}\text { Day } \\
\text { of } \\
\text { week }\end{array}$ & Participant's RT State & Message \\
\hline \multirow[t]{7}{*}{10} & \multirow[t]{7}{*}{2} & \multirow[t]{7}{*}{ Thurs } & $\begin{array}{l}\text { Telic-Conforming } \\
\text { Telic-Negativistic }\end{array}$ & $\begin{array}{l}\text { It will take time to reach your goal but sticking with your plan will get you there. } \\
\text { Be prepared to try something new to achieve something truly meaningful for yourself } \\
\text { on your health journey. }\end{array}$ \\
\hline & & & Paratelic-Conforming & $\begin{array}{l}\text { Think about your path to wellness as a game and something to be enjoyed. In games } \\
\text { we enjoy, rules seem to make it more fun to play. }\end{array}$ \\
\hline & & & Paratelic-Negativistic & $\begin{array}{l}\text { Just for today. Be bold doing what you want for fun. Go ahead, and do it with just } \\
\text { the "right" amount of bad. }\end{array}$ \\
\hline & & & Autic-Mastery & $\begin{array}{l}\text { The challenges you face are opportunities to show courage as you work for yourself } \\
\text { to maximize what your quality of life can become. }\end{array}$ \\
\hline & & & Autic-Sympathy & $\begin{array}{l}\text { As you go down this path don't hesitate to pamper yourself. You'll be better for it in } \\
\text { the long run and it just might be what you need. }\end{array}$ \\
\hline & & & Alloic-Mastery & $\begin{array}{l}\text { Let another survivor know that you believe in them and their capabilities to make a } \\
\text { difference in their lives toward a healthier, happier self. Knowing you believe in them } \\
\text { may help more than you might realize. }\end{array}$ \\
\hline & & & Alloic-Sympathy & $\begin{array}{l}\text { Compassion for a fellow survivor should never wait. Reach out to a fellow survivor } \\
\text { today and let them know you are in their corner in the battled-ridden road to healthier } \\
\text { selves. }\end{array}$ \\
\hline \multirow[t]{8}{*}{11} & \multirow[t]{8}{*}{2} & \multirow[t]{8}{*}{ Fri } & Telic-Conforming & Nobody said working on achieving those positive health goals would be easy. \\
\hline & & & Telic-Negativistic & $\begin{array}{l}\text { Try something new today, do it your way toward a healthier, happier you - defy all } \\
\text { the odds to make it happen. }\end{array}$ \\
\hline & & & Paratelic-Conforming & $\begin{array}{l}\text { Straight, narrow and enjoyable is the path toward getting to those goals that have been } \\
\text { set for your quality of life program. }\end{array}$ \\
\hline & & & Paratelic-Negativistic & $\begin{array}{l}\text { Fill your day today with some mischievous glee. Life is meant to be enjoyed even if } \\
\text { it means breaking a rule or two every once in a while. }\end{array}$ \\
\hline & & & Autic-Mastery & $\begin{array}{l}\text { You have your plan for making yourself a healthier you, be adamant, stick to your } \\
\text { guns and be bold in doing it for yourself. }\end{array}$ \\
\hline & & & Autic-Sympathy & $\begin{array}{l}\text { There is nothing wrong with allowing others the opportunity be kind to you. Let them } \\
\text { know what you need. }\end{array}$ \\
\hline & & & Alloic-Mastery & $\begin{array}{l}\text { Step outside yourself for a while and encourage someone else on their journey toward } \\
\text { health. They will more than probably appreciate your support. }\end{array}$ \\
\hline & & & Alloic-Sympathy & $\begin{array}{l}\text { Be a good friend, a good supporter for someone who needs it, always a good time to } \\
\text { reach out to someone who needs encouragement and help them on their way. }\end{array}$ \\
\hline \multirow[t]{8}{*}{12} & \multirow[t]{8}{*}{2} & \multirow[t]{8}{*}{ wknd } & Telic-Conforming & $\begin{array}{l}\text { Doing what's expected of you as you reach these goals for optimizing your health } \\
\text { and wellbeing can help bring you tranquility and inner peace. }\end{array}$ \\
\hline & & & Telic-Negativistic & $\begin{array}{l}\text { To reach your goal for a healthier you, old ways just won't cut it anymore. Be pre- } \\
\text { pared to re-invent yourself to succeed toward optimizing your well-being. }\end{array}$ \\
\hline & & & Paratelic-Conforming & $\begin{array}{l}\text { As you are following the pieces of the program set for you, ask yourself how you can } \\
\text { enjoy it more. Enjoy the ride. }\end{array}$ \\
\hline & & & Paratelic-Negativistic & $\begin{array}{l}\text { Take a detour and break the mold; truly enjoy the moment, the day and live the life } \\
\text { of freedom to do your thing. }\end{array}$ \\
\hline & & & Autic-Mastery & $\begin{array}{l}\text { The person who can challenge you the most to reach your health goals is the person } \\
\text { in the mirror. Master your approach in reaching what you want, a healthier, happier } \\
\text { you! }\end{array}$ \\
\hline & & & Autic-Sympathy & $\begin{array}{l}\text { Create a no-guilt zone that you can visit regularly, it just may do some good as you } \\
\text { go down this rough road toward a healthier you - (visit but don't stay forever). }\end{array}$ \\
\hline & & & Alloic-Mastery & $\begin{array}{l}\text { You can lighten someone's load by letting them know you believe in them to succeed; } \\
\text { sometimes a few words of encouragement can help other survivors at times when they } \\
\text { need it most. }\end{array}$ \\
\hline & & & Alloic-Sympathy & $\begin{array}{l}\text { It is ok to be compassionate for other survivors and let them know you care - pam- } \\
\text { per them with encouragement - it probably won't hurt, and it may just help them } \\
\text { tremendously to know they are in your thoughts. }\end{array}$ \\
\hline
\end{tabular}


Table 7

First Three Weeks of Support Messages Based on Reversal Theory State (Messages 13-15)

\begin{tabular}{|c|c|c|c|c|}
\hline $\begin{array}{l}\text { Msg } \\
\text { ID }\end{array}$ & Week & $\begin{array}{l}\text { Day } \\
\text { of } \\
\text { week }\end{array}$ & Participant's RT State & Message \\
\hline \multirow[t]{8}{*}{13} & \multirow[t]{8}{*}{3} & \multirow[t]{8}{*}{ Mon } & Telic-Conforming & $\begin{array}{l}\text { Your ultimate destination is a better version of you and what you can become. Please } \\
\text { keep going on this personal journey along this path you have begun. }\end{array}$ \\
\hline & & & Telic-Negativistic & $\begin{array}{l}\text { Ask yourself where you're headed and what's really important to you. Then be open } \\
\text { to the possibility of change for a healthier, happier version of you. }\end{array}$ \\
\hline & & & Paratelic-Conforming & $\begin{array}{l}\text { Knowing what to expect and meeting expectations of this program can make your } \\
\text { journey more fun as you travel toward a healthier, happier version of yourself. }\end{array}$ \\
\hline & & & Paratelic-Negativistic & $\begin{array}{l}\text { Enjoy yourself today as you defy the odds and try something new and bold, it is ok to } \\
\text { enjoy the ride and break the rules every once in a while for your total healthier you. }\end{array}$ \\
\hline & & & Autic-Mastery & $\begin{array}{l}\text { Be your own custom creation. Define yourself and activate yourself to reach what } \\
\text { you can ultimately be. }\end{array}$ \\
\hline & & & Autic-Sympathy & $\begin{array}{l}\text { There is nothing wrong with allowing others the opportunity be kind to you. Let them } \\
\text { know what you need. }\end{array}$ \\
\hline & & & Alloic-Mastery & $\begin{array}{l}\text { Your strength and your experiences can inspire others to succeed on their journey on } \\
\text { a healthier self. Use your experiences to be a strong force for good as a role model. }\end{array}$ \\
\hline & & & Alloic-Sympathy & $\begin{array}{l}\text { Compassion for a fellow survivor should never wait. Reach out to a fellow survivor } \\
\text { today and let them know you are in their corner in the battled-ridden road to healthier } \\
\text { selves. }\end{array}$ \\
\hline \multirow[t]{8}{*}{14} & \multirow[t]{8}{*}{3} & \multirow[t]{8}{*}{ Tues } & Telic-Conforming & $\begin{array}{l}\text { Healing is when your body, mind, spirit are in harmony. Achieve harmony by em- } \\
\text { bracing the path to optimal wellness that you have just begun. }\end{array}$ \\
\hline & & & Telic-Negativistic & $\begin{array}{l}\text { Be prepared to try something new to achieve something truly meaningful for yourself } \\
\text { on your health journey. }\end{array}$ \\
\hline & & & Paratelic-Conforming & $\begin{array}{l}\text { Think about your path to wellness as a game and something to be enjoyed. In games } \\
\text { we enjoy, rules seem to make it more fun to play. }\end{array}$ \\
\hline & & & Paratelic-Negativistic & $\begin{array}{l}\text { Old ways just will not cut it anymore. Have fun re-inventing yourself as you go down } \\
\text { this fun road less travel path toward your wellness. }\end{array}$ \\
\hline & & & Autic-Mastery & $\begin{array}{l}\text { The challenges you face are opportunities to show courage as you work for yourself } \\
\text { to maximize what your quality of life can become. }\end{array}$ \\
\hline & & & Autic-Sympathy & $\begin{array}{l}\text { Be kind to yourself. You deserve it. You may be hearing that a lot in the meditation } \\
\text { practices. }\end{array}$ \\
\hline & & & Alloic-Mastery & $\begin{array}{l}\text { Step outside yourself for a while and encourage someone else on their journey toward } \\
\text { health. They will more than probably appreciate your support. }\end{array}$ \\
\hline & & & Alloic-Sympathy & $\begin{array}{l}\text { Surprise someone today by reaching out to them and by telling them how much you } \\
\text { care for them and their well-being. }\end{array}$ \\
\hline \multirow[t]{8}{*}{15} & \multirow[t]{8}{*}{3} & \multirow[t]{8}{*}{ Wed } & Telic-Conforming & $\begin{array}{l}\text { Fully embracing your individual plan every day can help bring a strong sense of } \\
\text { personal purpose to your life. }\end{array}$ \\
\hline & & & Telic-Negativistic & $\begin{array}{l}\text { Try something new today, do it your way toward a healthier, happier you - defy all } \\
\text { the odds to make it happen. }\end{array}$ \\
\hline & & & Paratelic-Conforming & $\begin{array}{l}\text { Keep going straight along this path you've begun and enjoy every step of the journey. } \\
\text { Nothing wrong with having a little bit of fun. }\end{array}$ \\
\hline & & & Paratelic-Negativistic & $\begin{array}{l}\text { Spice up today's routine by doing something unexpected or new or something you } \\
\text { always want to try but were hesitant to do and enjoy the break from the expectations. }\end{array}$ \\
\hline & & & Autic-Mastery & $\begin{array}{l}\text { You have your plan for making yourself a healthier you, be adamant, stick to your } \\
\text { guns and be bold in doing it for yourself. }\end{array}$ \\
\hline & & & Autic-Sympathy & $\begin{array}{l}\text { As you go down this path don't hesitate to pamper yourself. You'll be better for it in } \\
\text { the long run and it just might be what you need. }\end{array}$ \\
\hline & & & Alloic-Mastery & $\begin{array}{l}\text { Set an example for someone who needs it, someone whose life you can touch on their } \\
\text { journey to better health. }\end{array}$ \\
\hline & & & Alloic-Sympathy & $\begin{array}{l}\text { Your sensitivity to the needs of other survivors can help them in special ways and at } \\
\text { time when they may need it most on their journey to a healthier happier self. }\end{array}$ \\
\hline
\end{tabular}


Table 8

First Three Weeks of Support Messages Based on Reversal Theory State (Messages 16-18)

\begin{tabular}{|c|c|c|c|c|}
\hline $\begin{array}{l}\text { Msg } \\
\text { ID }\end{array}$ & Week & $\begin{array}{l}\text { Day } \\
\text { of } \\
\text { week }\end{array}$ & Participant's RT State & Message \\
\hline \multirow[t]{8}{*}{16} & \multirow[t]{8}{*}{3} & \multirow[t]{8}{*}{ Thurs } & Telic-Conforming & Nobody said working on achieving those positive health goals would be easy. \\
\hline & & & Telic-Negativistic & $\begin{array}{l}\text { Ask yourself where you're headed and what's really important to you. Then be open } \\
\text { to the possibility of change for a healthier, happier version of you. }\end{array}$ \\
\hline & & & Paratelic-Conforming & $\begin{array}{l}\text { Straight, narrow and enjoyable is the path toward getting to those goals that have been } \\
\text { set for your quality of life program. }\end{array}$ \\
\hline & & & Paratelic-Negativistic & $\begin{array}{l}\text { Fill your day today with some mischievous glee. Life is meant to be enjoyed even if } \\
\text { it means breaking a rule or two every once in a while. }\end{array}$ \\
\hline & & & Autic-Mastery & $\begin{array}{l}\text { The person who can challenge you the most to reach your health goals is the person } \\
\text { in the mirror. Master your approach in reaching what you want, a healthier, happier } \\
\text { you! }\end{array}$ \\
\hline & & & Autic-Sympathy & $\begin{array}{l}\text { Don't shrink from asking for emotional support for yourself at any time. Most people, } \\
\text { especially those who care personally for you, want to help you achieve better health } \\
\text { but may not know how. }\end{array}$ \\
\hline & & & Alloic-Mastery & $\begin{array}{l}\text { Let another survivor know that you believe in them and their capabilities to make a } \\
\text { difference in their lives toward a healthier, happier self. Knowing you believe in them } \\
\text { may help more than you might realize. }\end{array}$ \\
\hline & & & Alloic-Sympathy & $\begin{array}{l}\text { Be a good friend, a good supporter for someone who needs it, always a good time to } \\
\text { reach out to someone who needs encouragement and help them on their way. }\end{array}$ \\
\hline \multirow[t]{8}{*}{17} & \multirow[t]{8}{*}{3} & \multirow[t]{8}{*}{ Fri } & Telic-Conforming & $\begin{array}{l}\text { Doing what is expected of you as you reach these goals for optimizing your health } \\
\text { and wellbeing can help bring you tranquility and inner peace. }\end{array}$ \\
\hline & & & Telic-Negativistic & $\begin{array}{l}\text { Be prepared to try something new to achieve something truly meaningful for yourself } \\
\text { on your health journey. }\end{array}$ \\
\hline & & & Paratelic-Conforming & $\begin{array}{l}\text { As you are following the pieces of the program set for you, ask yourself how you can } \\
\text { enjoy it more. Enjoy the ride. }\end{array}$ \\
\hline & & & Paratelic-Negativistic & $\begin{array}{l}\text { Take a detour and break the mold; truly enjoy the moment, the day and live the life } \\
\text { of freedom to do your thing. }\end{array}$ \\
\hline & & & Autic-Mastery & $\begin{array}{l}\text { Be fierce in your approach on the path toward to becoming a better, healthier, happier } \\
\text { version of yourself. }\end{array}$ \\
\hline & & & Autic-Sympathy & $\begin{array}{l}\text { Create a no-guilt zone that you can visit regularly, it just may do some good as you } \\
\text { go down this rough road toward a healthier you - (visit but don't stay forever). }\end{array}$ \\
\hline & & & Alloic-Mastery & $\begin{array}{l}\text { You can lighten someone's load by letting them know you believe in them to succeed; } \\
\text { sometimes a few words of encouragement can help other survivors at times when they } \\
\text { need it most. }\end{array}$ \\
\hline & & & Alloic-Sympathy & $\begin{array}{l}\text { It is ok to be compassionate for other survivors and let them know you care - pam- } \\
\text { per them with encouragement - it probably won't hurt, and it may just help them } \\
\text { tremendously to know they are in your thoughts. }\end{array}$ \\
\hline \multirow[t]{8}{*}{18} & \multirow[t]{8}{*}{3} & \multirow[t]{8}{*}{ wknd } & Telic-Conforming & $\begin{array}{l}\text { Your ultimate destination is a better version of you and what you can become. Please } \\
\text { keep going on this personal journey along this path you have begun. }\end{array}$ \\
\hline & & & Telic-Negativistic & $\begin{array}{l}\text { To reach your goal for a healthier you, old ways just won't cut it anymore. Be pre- } \\
\text { pared to re-invent yourself to succeed toward optimizing your well-being. }\end{array}$ \\
\hline & & & Paratelic-Conforming & $\begin{array}{l}\text { Life is a journey. Doing what is expected can make the journey less confusing and } \\
\text { every moment more enjoyable. }\end{array}$ \\
\hline & & & Paratelic-Negativistic & $\begin{array}{l}\text { Just for today. Be bold doing what you want for fun. Go ahead and do it with just the } \\
\text { "right" amount of bad. }\end{array}$ \\
\hline & & & Autic-Mastery & $\begin{array}{l}\text { You may not control everything that happens, but you can control everything that you } \\
\text { do. Positive changes make a positive difference toward your personal well being. }\end{array}$ \\
\hline & & & Autic-Sympathy & $\begin{array}{l}\text { Sometimes, you need to do what is best for your health. It is more than ok; it is } \\
\text { necessary to achieve that optimal life balance. Looking after yourself is not a bad } \\
\text { thing. }\end{array}$ \\
\hline & & & Alloic-Mastery & $\begin{array}{l}\text { Your strength can inspire others. Be a force for good as role model for others to } \\
\text { improve their health and well being. }\end{array}$ \\
\hline & & & Alloic-Sympathy & $\begin{array}{l}\text { Be the reason to be someone's joy. Your example may bring them cheer and cheer is } \\
\text { important for our mental well-being. }\end{array}$ \\
\hline
\end{tabular}


lowing the SSA approach allows the retention of practicallysignificant individual effects that are potentially lost otherwise. This form of analysis allows for assessment of the effectiveness of a treatment intervention for an individual in comparison to their starting baseline. The importance of this approach is shown in Figure 6, where the effect of the intervention for participant \#926 can be lost if just looking at the overall group results (Hughes, Leung, \& Naus, 2008). Though as a group these breast cancer survivors improved significantly on the Perceived Stress Scale (PSS), the impact for this individual (\#926) was much larger (effect size =1.43). Applying SSA is especially important for this holistic pilot as we are focusing on understanding the total impact of the intervention for each individual, not just for the group. SSA also allows a view of whether the intervention is effective before the intervention is complete. Therefore, if our algorithm to get the most effective messaging is not working for an individual, we can identify it and attempt to make modifications for that individual.

\section{Status of Pilot Project}

The University of Texas Health-San Antonio Institutional Review Board (IRB) approved the study. Once obtaining IRB approval, we opened the study up for enrollment and 30 survivors completed screening eligibility procedures and were scheduled for baseline assessments as a cohort over a long weekend. Twenty-nine participants provided informed consent and completed baseline assessments. The COVID19 pandemic temporarily delayed the intervention phase of the study.

\section{Concluding Statements}

The cancer experience challenges every survivor, potentially undermining a survivor's HR-QOL as it attacks all aspects of their daily existence. This can be overwhelmingly difficult to work through, leaving survivors with the need for an individualized, holistic program for them to regain, improve, and ultimately optimize their HR-QOL. We pilottested the protocol with volunteer cancer survivors, who also served on our advisory panel prior to beginning participant recruitment. Their results indicate the holistic approach does indeed seem feasible. However, to completely assess our holistic approach for feasibility, and to describe any efficacious results, we need to complete the study with our consented cohort of 29 survivors.

\section{References}

Ainsworth, B. E., Irwin, M. L., Addy, C. L., Whitt, M. C., Stolarczyk, L. M. (1999). Moderate physical activity patterns of minority women: the Cross-Cultural Activity Participation Study. J Womens Health Gend Based Med, 8(6), 805-813. doi:10.1089/152460999319129
American Cancer Society. (2019). Cancer Facts $\mathcal{F}$ Figures. American Cancer Society.

American College of Sports Medicine. (2018). ACSM's Guidelines for Exercise Testing and Prescription (10th ed.). Wolters Kluwer.

Apter International. (2004). Research Manual for the Apter Motivational Style Profile (AMSP). (pp. 46). Apter International, Ltd.

Apter, M. (2001). An Introduction to Reversal Theory. In M. Apter (Ed.), Motivational Styles in Everyday Life: A Guide to Reversal Theory (1 ed., pp. 3-37). American Psychological Association.

Arem, H., Moore, S. C., Park, Y., Ballard-Barbash, R., Hollenbeck, A., Leitzmann, M., \& Matthews, C. E. (2014). Physical activity and cancer-specific mortality in the NIHAARP Diet and Health Study cohort. Int J Cancer, 135(2), 423-431. doi:10.1002/ijc.28659

Bandura A. (1986). Social Foundations of Thought and Action (1st ed). Prentice-Hall

Basen-Engquist, K., Carmack, C. L., Perkins, H., Hughes, D., Serice, S., Scruggs, S., . . . Waters, A. (2011). Design of the Steps to Health Study of Physical Activity in Survivors of Endometrial Cancer: Testing a Social Cognitive Theory Model. Psychol Sport Exerc, 12(1), 27-35. doi:10.1016/j.psychsport.2010.07.010

Bellettieri R. (1993). Quality of Life - Before, During, and After Treatment. In: Squartini F, Bevilacqua G, Conte PF, Surbone A, eds. Breast Cancer: From Biology to Therapy (Vol 698, pp. 372-377). The New York Academy of Sciences.

Block, G., Gillespie, C., Rosenbaum, E. H., \& Jenson, C. (2000). A rapid food screener to assess fat and fruit and vegetable intake. Am J Prev Med, 18(4), 284-288. doi:S0749-3797(00)00119-7 [pii]

Bloom, M., Fischer, J., \& Orme, J. G. (2006). Evaluating Practice Guidelines for the Accountable Professional (5th ed.). Allyn \& Bacon, Pearson Education, Inc.

Bluethmann SM, Sciamanna CN, Winkels RM, Sturgeon KM, Schmitz KH. (2018). Healthy Living After Cancer Treatment: Considerations for Clinical and Community Practice. Am J Lifestyle Med, 12(3), 215-219.

Burris R, O'Connell K. (2003). Reversal theory states and cigarette availability predict lapses during smoking cessation among adolescents. Research in Nursing and Health, 26(4), 263-272.

Campbell, K. L., Winters-Stone, K. M., Wiskemann, J., May, A. M., Schwartz, A. L., Courneya, K. S., . . . Schmitz, K. H. (2019). Exercise Guidelines for Cancer Survivors: Consensus Statement from International Multidisciplinary Roundtable. Med Sci Sports Exerc, 51(11), 2375-2390. doi:10.1249/MSS.0000000000002116 
Cleeland CS, Mendoza TR, Wang XS, et al. (2000). Assessing symptom distress in cancer patients: the M.D. Anderson Symptom Inventory. Cancer, 89(7), 1634-1646.

Cook MR, Gerkovich MM, O'Connell KA, Potocky M. (1995). Reversal theory constructs and cigarette availability predict lapse early in smoking cessation. Res Nurs Health, 18(3), 217-224.

Costanzo ES, Stawski RS, Ryff CD, Coe CL, Almeida DM. (2012). Cancer survivors' responses to daily stressors: implications for quality of life. Health Psychology, 31(3), 360-370.

Courneya, K. S., Friedenreich, C. M., Reid, R. D., Gelmon, K., Mackey, J. R., Ladha, A. B., . . . Segal, R. J. (2009). Predictors of follow-up exercise behavior 6 months after a randomized trial of exercise training during breast cancer chemotherapy. Breast Cancer Res Treat, 114(1), 179-187. doi:10.1007/s10549-008-9987-3

Desselles, M. L., Murphy, S. L., \& Theys, E. R. (2014). The Development of the Reversal Theory State Measure. Journal of Motivation, Emotion, and Personality, 2(1), 10-21.

Farris, M. S., Courneya, K. S., O'Reilly, R., \& Friedenreich, C. M. (2018). Psychosocial Outcomes 12 Months Following a Dose-Response Aerobic Exercise Intervention in Postmenopausal Women. J Phys Act Health, 15(3), 219225. doi:10.1123/jpah.2017-0282

Friedenreich, C. M., Neilson, H. K., Farris, M. S., \& Courneya, K. S. (2016). Physical Activity and Cancer Outcomes: A Precision Medicine Approach. Clin Cancer Res, 22(19), 4766-4775. doi:10.1158/1078-0432.CCR16-0067

Harms CA, Cohen L, Pooley JA, Chambers SK, Galvao DA, Newton RU. (2019). Quality of life and psychological distress in cancer survivors: The role of psycho-social resources for resilience. Psycho-oncology, 28(2), 271-277.

Hughes, D. C., Baum, G. P., Perkins, H. Y., \& BasenEngquist, K. M. (2009). Metamotivational States and Exercise Behaviors in Previously Sedentary Endometrial Cancer Survivors. Paper presented at the 14th International Reversal Theory Conference, New Orleans, LA.

Hughes, D. C., Garcia, S. D., Treviño, L., Morris, R., \& Ramirez, A. G. (2013). Promotion of Exercise In Latina Cancer Survivors. Paper presented at the The United States-México Border Health Commission, México Border Obesity Prevention Summit, McAllen Texas.

Hughes, D. C., Leung P., Naus M.J. (2008). Using singlesystem analyses to assess the effectiveness of an exercise intervention on quality of life for Hispanic breast cancer survivors: a pilot study. Soc Work Health Care, 47(1), 7391.

Ladabaum, U., Mannalithara, A., Myer, P. A., \& Singh, G. (2014). Obesity, abdominal obesity, phys- ical activity, and caloric intake in US adults: 1988 to 2010. Am J Med, 127(8), 717-727 e712. doi:10.1016/j.amjmed.2014.02.026

Mustian, K. M., Alfano, C. M., Heckler, C., Kleckner, A. S., Kleckner, I. R., Leach, C. R., . . . Miller, S. M. (2017). Comparison of Pharmaceutical, Psychological, and Exercise Treatments for Cancer-Related Fatigue: A Meta-analysis. JAMA Oncol, 3(7), 961-968. doi:10.1001/jamaoncol.2016.6914

National Cancer Institute. (2019). Research Emphasis. https://cancercontrol.cancer.gov/research-emphasis/

Newton, R. U., Kenfield, S. A., Hart, N. H., Chan, J. M., Courneya, K. S., Catto, J., . . Saad, F. (2018). Intense Exercise for Survival among Men with Metastatic CastrateResistant Prostate Cancer (INTERVAL-GAP4): a multicentre, randomised, controlled phase III study protocol. BMJ Open, 8(5), e022899. doi:10.1136/bmjopen-2018022899

O'Connell KA, Gerkovich MM, Cook MR. (1995). Reversal theory's mastery and sympathy states in smoking cessation. Image J Nurs Sch, 27(4), 311-316.

Popkess-Vawter S, Wendel S, Schmoll S, O'Connell K. (1998). Overeating, reversal theory, and weight cycling. West J Nurs Res, 20(1), 67-83.

Satija, A., \& Bhatnagar, S. (2017). Complementary Therapies for Symptom Management in Cancer Patients. Indian J Palliat Care, 23(4), 468-479. doi:10.4103/IJPC.IJPC_100_17

Schwartz, A. L., de Heer, H. D., \& Bea, J. W. (2017). Initiating Exercise Interventions to Promote Wellness in Cancer Patients and Survivors. Oncology (Williston Park), 31(10), 711-717. Retrieved from http://www.ncbi.nlm.nih.gov/pubmed/29083464

Sit CHP, Kerr JH, Wong ITF. (2008). Motives for and barriers to physical activity participation in middle-aged Chinese women. Psychology of Sport and Exercise, 9, 266283.

Squires, R. W., Shultz, A. M., \& Herrmann, J. (2018). Exercise Training and Cardiovascular Health in Cancer Patients. Curr Oncol Rep, 20(3), 27. doi:10.1007/s11912018-0681-2

U.S. Department of Health and Human Services. (2018). Physical Activity Guidelines for Americans, 2nd edition Retrieved from www.health.gov/PAGuidelines Retrieved from www.health.gov/PAGuidelines

Witter DC, Le Bas J. Anderson cancer center: Cancer as a chronic disease. Oncol Rep Physicians. 2008(53), 1-5. 